\title{
磁界解析に基づいた短二次りニア誘導電動機 の等価回路
}

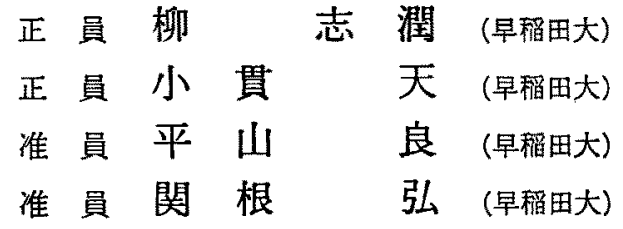

\section{1.はしがき}

リニア誘導電動機（以下 LIM と称する）は，高速 交通手段や工場内生痤ラインなど, 直線運動が要求さ れる産業分野において歯車などの補助器具が不要とな るとと，磁気浮上と結合した場合には非接触駆動が可 能であるととなどの利点から広い忘用が期待されてい る。特に短二次 LIM は，二次導体が軽量に製作でき るのて，急激な加減速運輀兮可能であり，またパンタ グラフの不要など多くの長所を有している。しかしな がら，LIM の特性解析はその構造的特質である端効 果のために相当複雑になる。特性解析面では，近年盛 んに行われている電磁界の数值解析法によって十分満 足され得る結果を算出でき，かつ計測が困難な䇢所の 諸量についても算定加可能となっている。しかし，数 值解析の手法直接制裉传用いるのは簡単ではない。 一方，回転機の上うに等価回路を解析の手段とする方 法が考えられるが, LIM はその入口，出口端におい ての電気的磁気的条件が変化するために，回転機のよ うな対称性が成立しないので，回転機化対する等価回 路をそのまま適用するてとはできず，それなりの等価 回路を作る必要がある。

このような状況下で短一次 LIM の等価回路につい て幾つかの研究がある(1)(2)。端効果を考虑したてれら の等価回路は，定常状態特性を評価するには有益な情

\footnotetext{
Equivalent Circuit of Short Rotor Linear Induction Motor Based on Magnetic Field Analysis. By Shijun Ryu, Member,

Takashi Onuki, Member, Ryou Hirayama, Associate \&

Hiroshi Sekine, Associate (Department of Electric Engineering,

Waseda University).

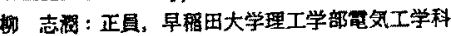

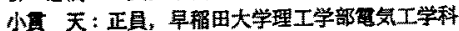

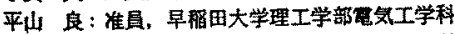

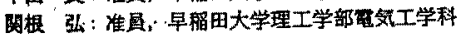

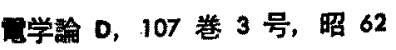

報を与えるものであるが，正弦波定常電流を前提とし ているたる，時間的過渡状態们対しては端効果の表現 が必ずしも適切とは言い難い。

Lipo 氏ら ${ }^{(3)}$ は “Pole by pole d-q model”.を提案 し，短一次 LIM の過渡书よび定常状態解析を可能之 した。それはかなり有用なアプローキてあると考えら れる。しかし, 短二次 LIM の場合は, 二次導体が空 げき内に限定され，しかむ移動時には文献（3）のよう な巻線関数をそのまま適用することはできない。本論 文では，短二次両側式り二了誘導電動機（以下，短二 次 DLIM 之称する）に対する等価回路を䤃出するた めに，マクスウェル方程式加ら得られる空げき磁束密 度の解から，道切であると思われる二次巻楾関数を仮

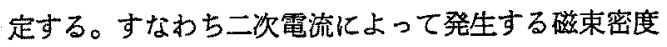
加ら, 逆に二次電流の時間的変化亡空間的分布を導出 する。そして，その空間的分布を生ずるような巻線を 二次導体上に仮定し，ちの分布状態を関数で表現して 二次巻楾関数之定義する。 次巻線関数を用い，回転機に適用されている定数計算 法化従って二軸等価回路を導出する。すなわち，短 二次 DLIM において，複雥な電磁界の問題を制御に 適用可能なように回路化するための道を開拓しようと するすのである。

この等価回路によれば，端効果を考慮し更に時間的 過渡状態です特性の解析が可能である。最後に，供試 機に対する計算および実測結果之の比較を示した後， それらの結果を用いたサーボ制御について報告する。

\section{2. 等価回路の導出}

〈2.1〉仮定および基礎方程式 四1のような簡 単化された短二次 DLIM のモデルに対して一次元近 


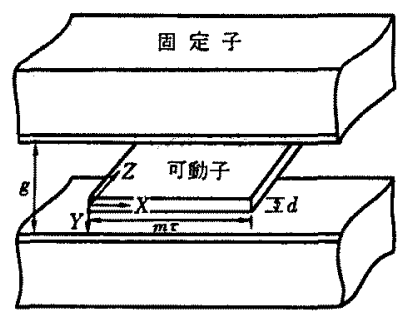

図 1 短二次両側式りニア誘導電動機

Fig. 1. Analitical model of the short rotor double sided LIM.

似を行う。すなわち， $Z$ 方向は無限長を有し一様の現 象を呈するすのとし，その単位長あたりについて考察 することにする。また，鉄心の透磁率怯無限大と仮定 し，Y方向に関しても一様の現象が現れるあのとす る。また進行磁界, 二次導体ともに $x$ の正方向に進 んでいる場合を考え，座標を二次導体上にとる。

本論文で使用する文字を次のように定義する。

$I_{s}:$ 一次電流の最大值 $(\mathrm{A})$

$I_{\boldsymbol{r}}$ : 二次電流の最大值 $(\mathrm{A})$

$\bar{B}_{s r}(x, t): \bar{I}_{s}(t)$ ¿ $\bar{I}_{r}(t)$ に上万磁束密度 $(\mathrm{T})$ ( $Y$ 方向)

$\bar{B}_{s}(x, t): \bar{I}_{s}(t)$ 亿よる磁束密度 ( $\left.\mathrm{T}\right)$ ( $Y$ 方向)

$\bar{B}_{r}(x, t): \bar{I}_{r}(t)$ 飞よる磁束密度 $(\mathrm{T})$ ( $Y$ 方向 $)$

$\bar{E}_{r}:$ 二次誘起電圧 $(\mathrm{V})$

$\bar{H}_{r}:$ 二次磁界の強さ $(\mathrm{Wb})$

$\bar{J}_{r}$ : 二次電流分布の最大電流密度 $(\mathrm{A} / \mathrm{m})$

$N_{a s}(x), N_{b s}(x), N_{c s}(x):$ 一次側 $(s) a, b, c$ 相の 巻線関数

$N_{r}(x)$ : 二次巻線関数

$N_{r r}$ : 二次巻線関数における空間的基本波 $(f)$ 成 分の最大巻数 (Turn)

$N_{r T 1}, N_{r} T 2$ : 二次巻線関数における入口端 $\left(T_{1}\right)$ と出口端 $\left(T_{2}\right)$ 端効果成分の最大巻数 (Turn) g:カーター係数によって補正された実効空げき 長 $(\mathrm{m})$

$\mu_{0}:$ 空気の透磁率, $\rho:$ 二次導体面抵抗率

$s:$ すべり, $\tau:$ 極長 $(\mathrm{m})$

$m:$ 長さを $\tau$ で表す場合の乗数

磁束密度に関する偏微分方程式を誘導するために， 次のように微分形マクスウェル方程式を変形してい く。

$$
\begin{aligned}
& \nabla \times \bar{E}_{r}=-\partial \bar{B}_{s r} / \partial t \\
& \bar{B}_{s r}=\bar{B}_{s}+\bar{B}_{r} \ldots \ldots . \\
& \nabla \times \bar{H}_{r}=\bar{J}_{r} / g \ldots \ldots . \\
& \nabla \times\left(\bar{B}_{r} / \mu_{0}\right)=\bar{J}_{r} / g .
\end{aligned}
$$

上記関係を用いると，磁束密度に関する一般式は，

$$
-\frac{\rho g}{\mu_{0}} \cdot \frac{\partial^{2} \bar{B}_{r}}{\partial x^{2}}-\frac{\partial \bar{B}_{r}}{\partial t}=\frac{\partial \bar{B}_{s}}{\partial t}
$$

のように表される。

\section{〈2.2〉磁東分布およひ兴線関数}

（1）巻線関数と一次磁束密度分布 アンペア則 により

$$
\oint \bar{H} \cdot d \bar{l}=I \cdot N(x)
$$

ここでは鉄の透磁率を無限大と仮定しているので次式 となる。

$$
g \cdot \bar{H}(x)=I \cdot N(x)
$$

(7) 式を磁束密度を用いて表せば

$$
\bar{B}(x, t)=\left(\mu_{0} / g\right) \bar{I}(t) \cdot N(x)
$$

の関係が成立する。

ここで, $t=0$ で一次侧座標系 $x^{\prime}$ の原点加ら $m \tau$ 離 れた位置に二次導体が停止していると考え，一次巻線 関数を二次座標系上で表すと

$$
\left.\begin{array}{l}
N_{a s}(x)=\left(N_{s} / 2\right) \cos (\pi x / \tau+\pi) \\
N_{b s}(x)=\left(N_{s} / 2\right) \cos (\pi x / \tau+\pi / 3) \\
N_{c s}(x)=\left(N_{s} / 2\right) \cos (\pi x / \tau-\pi / 3)
\end{array}\right\}
$$

ただし， $N_{t}=K_{W} \cdot N\left(K_{W}\right.$ は巻線係数， $N$ は

巻数)

上式の巻線関数を三相-二相変換 ᄂ， $\alpha-\beta$ 軸巻楾関数 を求めると

$$
\left.\begin{array}{l}
N_{\alpha s}(x)=(3 / 4) N_{s} \sin (\pi x / \tau) \\
N_{\beta s}(x)=-(3 / 4) N_{s} \cos (\pi x / \tau)
\end{array}\right\}
$$

(8)式と (10)式の関保加ら,

$$
\begin{aligned}
\bar{B}_{s}(x, t)= & -\left(3 \mu_{0} / 4 g\right) N_{s} I_{s} \\
& \times \exp \{j(s \omega t-\pi x / \tau)\}
\end{aligned}
$$

になる。

（2）二次磁束密度分布 二次磁束密度は空間的 基本波成分之端効果成分に分類して考察するととにす る。

(i) 空間的基本波成分 $\bar{B}_{r}(x, t)$ は

$$
\begin{aligned}
\bar{B}_{r}(x, t) & =N_{r f}(x) \bar{I}_{r}(t) \\
& =B_{r f} \exp \left\{j\left(s \omega t-\pi x / \tau+\delta_{s}\right)\right\}
\end{aligned}
$$

の形をすつとして，(11)，(12)式を(5)式に代入して 解く之 $\bar{B}_{r}(x, t)$ の空間的基本波成分 $\bar{B}_{r f}(x, t)$ は

$$
\begin{aligned}
\bar{B}_{r f}(x, t)= & N_{r} \exp \{-j \pi x / \tau\} \\
& \times I_{s} \exp \left\{j\left(s \omega t+\delta_{s}\right)\right\}
\end{aligned}
$$

となる。(13)式て $N_{r}(x)$ の空間的基本波成分 $N_{r f}(x)$ を書き直すと

$$
N_{r f}(x)=-N_{r} \exp (-j \pi x / \tau)
$$


とこで,

$$
\begin{aligned}
& N_{\tau}=-3 \cdot N_{s} / 4 \cdot\left\{\sqrt{(1 / s G)^{2}+1}\right\} \\
& G=2 \mu_{0} \tau^{2} f /(\pi \rho g) \ldots \ldots \ldots \ldots \ldots \ldots \ldots \ldots \ldots \ldots \ldots \ldots \ldots \ldots \ldots \ldots
\end{aligned}
$$

となる。

(ii) 端効果成分 端勏果成分活，(5)式の同次 方程式の過洨解として得られるので $\bar{B},(x, t)$ を $N_{r}(x)$ と $\bar{I}_{r}(t)$ 飞後数分離し(5)式の右分を等とおいて解 ২。

$$
\frac{\rho g}{\mu_{0}} \frac{\partial^{2} N_{r}(x) \bar{I}_{r}(t)}{\partial x^{2}}-\frac{\partial N_{r}(x) \bar{I}_{r}(t)}{\partial t}=0
$$

ここで，任意の装数 $\lambda$ を導入すると，

$$
\frac{\rho g}{\mu_{0}} \frac{1}{N_{r}(x)} \frac{\partial^{2} N_{r}(x)}{\partial x^{2}}=\frac{1}{\bar{I}_{r}(t)} \frac{\partial \bar{I}_{r}(t)}{\partial t}=\lambda
$$

$N_{r}(x)$ 占 $\exp (k x)$ の形を有吉ると仮定し(19)式に代 入すると

$$
k^{2}-\frac{\mu_{0}}{\rho g} \lambda=0, \quad k_{1,2}= \pm \sqrt{\frac{\mu_{0}}{\rho g}} \lambda
$$

加求められる。従って, $N_{r}(x)$ の端效果成分 $N_{r} r(x)$ H

$$
N_{r T}(x)=N_{r T 1} \exp \left(k_{1} x\right)+N_{r T 2} \exp \left(k_{2} x\right)
$$

となる。

空間的基本波成分（(14)式) と端効果分（(21)式) を含んだ $N_{r}(x)$ は

$$
\begin{aligned}
N_{r}(x)= & N_{r f}(x)+N_{r T}(x) \\
= & -N_{r} \exp (-j \pi x / \tau) \\
& +N_{r T 1} \exp \left(k_{1} x\right)+N_{r T 2} \exp \left(k_{2} x\right)
\end{aligned}
$$

と書くことができる。

(3) 端効果成分の湌討 LIM におりる空げき 磁束密度の空間的基本波成分は，回転機の場合と同じ く電流の変化に直接比例する。しかし，端効果成分に

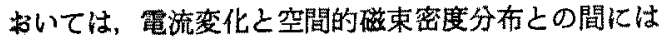

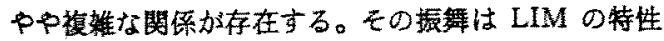
に招いて重要な因子となるのて，LIM の定常連転時 と䢔渡運転時に分けて考察する。

（i）定常状態解 電動機の定常状態動作におい ては，(19)式の入は純粋な虚数部のみをあち，実数部 をむたない。従って，一次電流は角周波数 $\omega$ をあつ

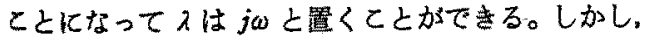
座標委を二次側飞固定した場合にはjs心 としなりれ ばならいのて

$$
\lambda_{s t}=j s \omega
$$

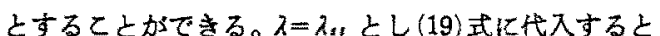

$$
k_{1,2}= \pm \sqrt{j s G} \pi / \tau
$$

上って

$$
\begin{aligned}
N_{r}(x)= & -N_{r} \exp (-j \pi x / \tau) \\
& +N_{r T 1} \exp (-V \overline{j s G} \pi x / \tau) \\
& +N_{r 2} \exp (V \overline{j s G} \pi x / \tau) \ldots .
\end{aligned}
$$

の解が得られる。

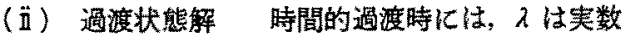
部と虚数部をるつとして

$$
\lambda_{T}=a+j s \omega .
$$

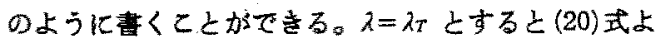
b

$$
k_{1,2}= \pm \sqrt{\frac{\mu_{0} \tau^{2}}{\rho g \pi^{2}} a+j s G} \frac{\pi}{\tau}
$$

となる加

$$
\begin{aligned}
& a^{\prime}+\sqrt{2 a^{\prime}(s G)^{\prime}}=a \ldots \ldots . \\
& (s G)^{\prime}+\sqrt{2 a^{\prime}(s G)^{\prime}}=s G .
\end{aligned}
$$

の関係を用いると，

$$
k_{1,2}= \pm\left(\sqrt{\frac{\mu_{0} \tau^{2}}{\rho g \pi^{2}}} a^{\prime}+\sqrt{j(s G)^{\prime}}\right) \frac{\pi}{\tau}
$$

と書くことができる。(30)式を(22)式に代入すると

$$
\begin{aligned}
N_{r}(x)= & -N_{r} \exp (-j \pi x / \tau) \\
& +N_{r T 1} \exp \left\{-\sqrt{\left(\mu_{0} \tau^{2} / \rho g \pi^{2}\right) a^{\prime}} \pi x / \tau\right\} \\
& \times \exp \left\{-\sqrt{j(s G)^{\prime}} \pi x / \tau\right\} \\
& +N_{r T 2} \exp \left\{\sqrt{\left(\mu_{0} \tau^{2} / \rho g \pi^{2}\right) a^{\prime}} \pi x / \tau\right\} \\
& \times \exp \left\{\sqrt{j(s G)^{\prime}} \pi x / \tau\right\} \ldots \ldots \ldots(31)
\end{aligned}
$$

となる。(26)式のaの算定にあたっては，二次電流を

$$
\begin{aligned}
\bar{I}_{r}(t) & =I_{r}\{\exp (a+j s \omega) t\} \\
& =I_{r} \exp (a t)(\cos s \omega t+j \sin s \omega t) \ldots
\end{aligned}
$$

の形を有するとすると， $I_{r}(t)$ の振蝠を決定するには (32)式の第1 項、または第 2 項中のどちらが考えて 㐫上以。徒って

$$
I_{r} \exp (a t)=\tilde{I}_{r}(t) / \cos (s \omega t)
$$

が成立する。ここで，ある時刻 $t_{n-1}$ での振幅を $I_{r, n-1}$, $t_{n}$ で值を $I_{t . n}$ とし、 $t_{n}-t_{n-1}=\Delta t$ とすると

$$
I_{r, n-1} \exp (a \Delta t)=I_{r, n}
$$

の関係加成り立つ。また

$$
\exp (a \Delta t)=I_{r, n} / I_{r, n-1}
$$

になって

$$
a=\ln \left(I_{r, n} / I_{r, n-1}\right) / \Delta t
$$

として求めることができる。

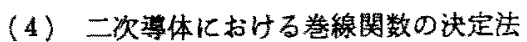
式は定常のとき $a=0$ とすると，定常状態书よび過渡 状態で共に成立する式であることがわかる。 


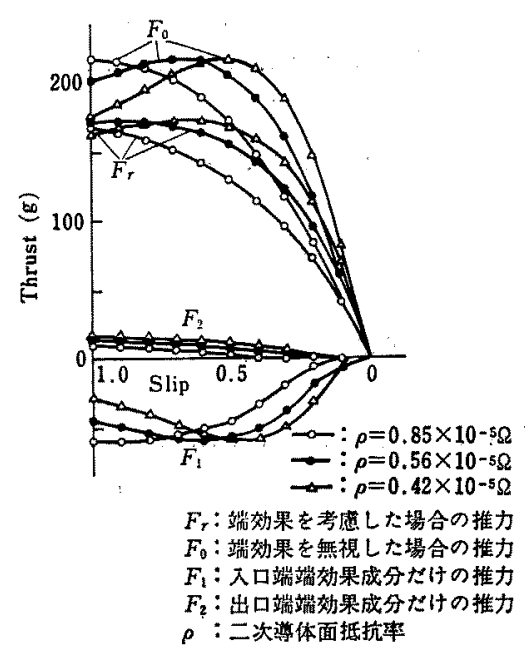

図 2 短二次 DLIM のすべりー推力特性

Fig. 2. Slip-thrust characteristics of short rotor DLIM.

$$
\begin{aligned}
& \sqrt{j}=(1+j) / \sqrt{2} \ldots \\
& \sqrt{\frac{\mu_{0} \tau^{2}}{\rho g \pi^{2}}} a^{\prime}+\sqrt{\frac{s G^{\prime}}{2}}=C \\
& \sqrt{(s G)^{\prime} / 2}=D \ldots \ldots \ldots .
\end{aligned}
$$

とすると(26)式は

$$
\begin{aligned}
& N_{r}(x)=-N_{r} \exp (-j \pi x / \tau) \\
& \quad+N_{r T 1} \exp (-C \pi x / \tau) \times \exp (-j D \pi x / \tau) \\
& \quad+N_{r T 2} \exp (C \pi x / \tau) \times \exp (j D \pi x / \tau)
\end{aligned}
$$

のように簡単に書くことができる。とこで第 1 項は回 転機之同様の空間的基本波成分，第 2 項は入口端加 の減衰進行波, 第3 項は出口端での反射波である。㘡 2 は参考文献 (4)から転載したあのであり，上記各項 の推力特性を表すものである。その解析結果からわか るように，第 3 項成分の推力への影響は第 2 項と比へ ると少なく，無視しても実用上問題ないので，本文で は以降第 1 項，第 2 項だけを考虑するととにする。

ここで $N_{r T 1}, N_{r T 2}$ を求めるために境界条件として 磁束の連続性を考える。すなわち，二次導体の左右両 端である $x=0$ および $x=m \tau$ において, 負荷部 $(0 \leq$ $x \leq m \tau)$ に扰りる磁束密度 $\bar{B}_{a r}(x, t)$ は無目荷部の磁 束密度 $\bar{B}_{s}(x, t)$ と等しくなりればならないという関 係を用いて

$$
\begin{aligned}
N_{r T \mathrm{I}}= & N_{r} \times\{\exp (-j m \pi) \\
& -\exp (C m \pi) \times \exp (j D m \pi)\} \\
& /\{\exp (-C m \pi) \times \exp (-j D m \pi) \\
& -\exp (C m \pi) \times \exp (j D m \pi)\} \ldots(41)
\end{aligned}
$$

$$
\begin{aligned}
N_{r T 2}= & N_{r} \times\{-\exp (-j m \pi) \\
& +\exp (-C m \pi) \times \exp (-j D m \pi)\} \\
& /\{\exp (-C m \pi) \times \exp (-j D m \pi) \\
& -\exp (C m \pi) \times \exp (j D m \pi)\} \ldots(42)
\end{aligned}
$$

の上うに求められる。

結果的に二次磁束の $Y$ 成分は (40)，(41)，(42)式の 組合せとして表され，また等価的に仮想される二次導 体上の巻線関数は(40)式の実数部が $\beta$ 軸, 虚数部加 $\alpha$ 軸として

$$
\begin{aligned}
N_{\alpha r}(x)= & N_{r} \sin (\pi x / \tau) \\
- & N_{r T 1} \exp (-C \pi x / \tau) \times \sin (D \pi x / \tau) \\
+ & N_{r T 2} \exp (C \pi x / \tau) \times \sin (D \pi x / \tau) \\
& \quad \ldots \ldots \ldots \ldots \ldots \ldots \ldots \ldots \ldots \ldots \ldots \ldots \ldots \ldots \ldots \ldots \ldots \\
N_{\beta r}(x)= & -N_{r} \cos (\pi x / \tau) \\
+ & N_{r T 1} \exp (-C \pi x / \tau) \times \cos (D \pi x / \tau) \\
+ & N_{r T 2} \exp (C \pi x / \tau) \times \cos (D \pi x / \tau)
\end{aligned}
$$

と書くことができる。参考として，定常状態での (43)， (44)式による $\alpha, \beta$ 軸巻線関数の様子を図 3 亿示す。

結局, 前述の関係および〈2・3〉節での等価回路定数 計算法侸よって作られる等価回路は表1のような条件 下で成立するものである。

$\langle 2 \cdot 3\rangle$ 等価回路定数計算法 等価回路におりる 諸定数は, 短二次 DLIM の場合には空げき内に二次 導体が限定されており，端効果のために回転機のよう 亿基碄実験から回路定数を求めることはできない。よ って，その算出においては以下に述べる計算式を用い ることにする。

（1）二巻線間の相互インダクタンス 前述の巻 線関数はある与えられた巻線に対する磁束分布を表す ものであり，二巻線間のインダクタンスは次のように 簡単に計算できる。

$$
L_{1,2}=\frac{\mu_{0} w}{g} \int_{0}^{P_{\tau}} N_{1}(x) N_{2}(x) d x
$$

（2）速度起電力係数 二次導体が動く際には変 王器起電力以外化速度起電力が生じる。基準座標系を 一次鉄心におく之速度起電力は二次導体上のみに誘起 され，回路 1 が動く之き回路 2 によって回路 1 に誘起 される電压 $e_{1,2}$ 住

$$
\begin{aligned}
e_{1,2} & =\frac{d x}{d t} i_{2} \frac{\partial L_{1,2}}{\partial x} \\
& =\frac{\pi}{\tau} V_{r} i_{2}\left(\frac{\tau}{\pi} \frac{\partial L_{1,2}}{\partial x}\right) .
\end{aligned}
$$

と書くことができる。ここで, $\pi V_{r} / \tau$ は回転機での機

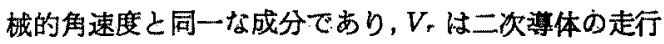




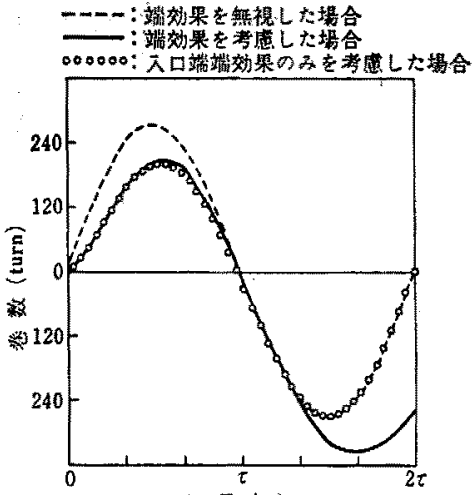

槡 $(\mathbf{m})$

（a） $\alpha$ 垶巻釈閔数

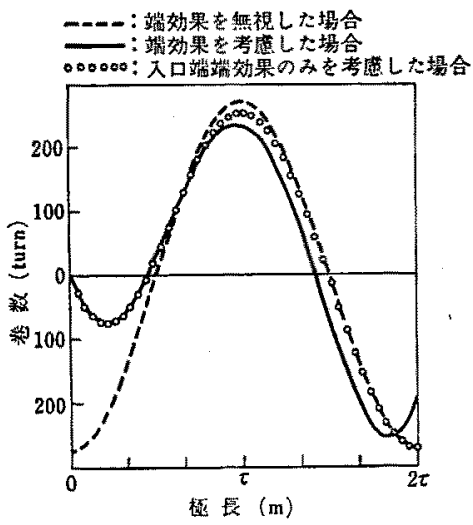

(b) $\beta$ 䡩巻家衈数

图 3 二次側巻線関数

Fig. 3. The rotor winding function.

表 1 本等価回路が有効である畤間空間的条件 Table 1. The conditions considerd for the analysis.

\begin{tabular}{|c|c|c|c|}
\hline \multicolumn{2}{|c|}{ 空 間 間 } & 定常楼惒 & 過渡状盟 \\
\hline \multicolumn{2}{|c|}{ 基本波成分 } & 0 & 0 \\
\hline \multirow{2}{*}{ 端效果分 } & 入口端 & 0 & $\mathrm{O}$ \\
\hline & 出口端 & $x$ & $x$ \\
\hline
\end{tabular}

速度である。速度起電力係数を

$$
G_{1,2}=\frac{\tau}{\pi} \frac{\partial L_{1,2}}{\partial x}
$$

のように表すと，巻線関数を用い

$$
G_{1,2}=\left.\frac{\tau}{\pi} \frac{\mu_{0} w}{g} \int_{0}^{P_{\tau}} N_{1}(x) \frac{\partial N_{2}(x+\phi)}{\partial \phi}\right|_{\phi=0} d x
$$

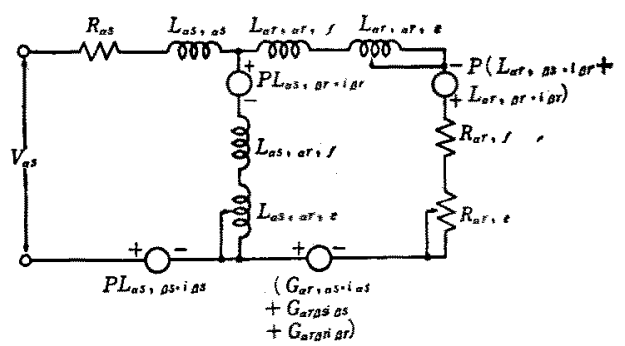

（a） $\alpha$ 韩等価回路

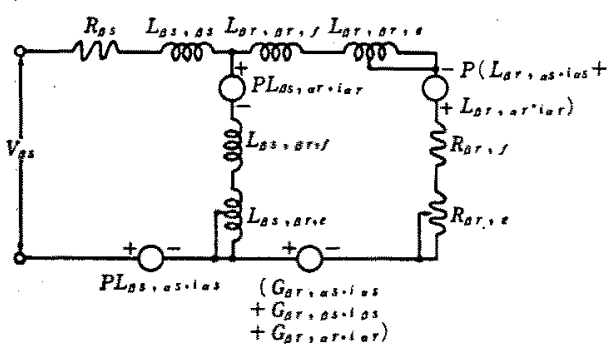

(b) $\beta$ 軸等価回路

图 4 短二次雨側式リニアモータの

$\alpha-\beta$ 雗等価回路

Fig. 4. The $\alpha-\beta$ axis equivalent circuit of the short rotor double sided LIM.

（3）二次抵抗 二次導体抵抗値の算定において は, 次のように Goodness factor を用い求める。

Goodness factor $G=X_{m} / R_{2}$ )

$R_{2}=X_{m} / G$

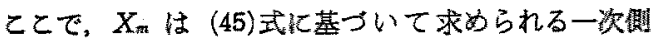
と二次側間の相互インダクタンスに関する等価インピ 一ダンスである。

前还の関係を用い結果的に得られた短二次 DLIM の $\alpha, \beta$ 翰等硒回路㥗 40ようになる。等価回路中 のパラメー夕添字 $f$ および $e$ の付いた李のは，そ れぞれ空間的基本波成分と端效果分を澺味している量 であり，添字のないるのは雨成分を含えだ量であるこ とを示している。また，端効果分要素はすべり 5 と 一次管流 $\bar{I}_{s}(t)$ の䦭数となっている。

\section{3. 等価回路から導かれる電圧一電流方程式}

ここでは以上に求めた LIM の等洒回路を，一般の 回転機に対して開発された二軸理論に組込み，その取

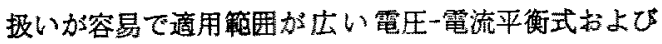
状態空間表現法について述へる。まず，電压一電流平 衡式を行列形式で書くと

$$
[\bar{V})=(\bar{R})(\bar{i})+(\bar{L}) \frac{d(\bar{i})}{d t}+\frac{\pi}{\tau} V_{r}(\bar{G})(\bar{i})
$$


のようになる。とてで

$$
\begin{aligned}
& \because(\bar{V})=\left[V_{\alpha s}, V_{\beta s}, V_{\alpha r}, V_{\beta r}\right)^{T} \\
& {[i]=\left[i_{\alpha s}, i_{\beta s}, i_{\alpha r}, i_{\beta \tau}\right]^{r}} \\
& {[\bar{R}]=\left[\bar{R}_{r}\right]+\left[\bar{R}_{T}\right]} \\
& =\operatorname{diag}\left[R_{\alpha s}, R_{\beta s}, R_{\alpha r, f}, R_{\beta r, f}\right\} \\
& +\operatorname{diag}\left[0,0, R_{\alpha r, T}, R_{\beta r, T}\right] \\
& {[\bar{L})=\left(\bar{L}_{f}\right]+\left\{\bar{L}_{r}\right)} \\
& =\left(\begin{array}{llll}
L_{\alpha s, \alpha s} & L_{\alpha s, \beta s} & L_{\alpha s, \alpha \tau, f} & L_{\alpha s, \beta r, f} \\
L_{\beta s, \alpha s} & L_{\beta s, \beta s} & L_{\beta s, \alpha \tau, f} & L_{\beta s, \beta r, f} \\
L_{\alpha r, \alpha s, f} & L_{\alpha r, \beta s, f} & L_{\alpha r, \alpha r, f} & L_{\alpha r, \beta r, f} \\
L_{\beta r, \alpha s, f} & L_{\beta r, \beta s, f} & L_{\beta r, \alpha r, f} & L_{\beta r, \beta r, f}
\end{array}\right] \\
& +\left[\begin{array}{cccc}
0 & 0 & L_{\alpha s, \alpha r, T} & L_{\alpha s, \beta r, T} \\
0 & 0 & L_{\beta s, \alpha r, T} & L_{\beta s, \beta r, T} \\
L_{\alpha r, \alpha s, T} & L_{\alpha r, \beta s, T} & L_{\alpha r, \alpha r, T} & L_{\alpha r, \beta r, T} \\
L_{\beta r, \alpha s, T} & L_{\beta r, \beta s, T} & L_{\beta r, \alpha r, T} & L_{\beta r, \beta r, T}
\end{array}\right] \\
& {[\bar{G}]=\left[\bar{G}_{r}\right]+\left[\bar{G}_{r}\right]} \\
& =\left[\begin{array}{cccc}
0 & 0 & 0 & 0 \\
0 & 0 & 0 & 0 \\
G_{\alpha r, \alpha s, f} & G_{\alpha r, \beta s, f} & 0 & G_{\alpha r, \beta r, f} \\
G_{\beta r, \alpha s, f} & G_{\beta r, \beta s, f} & G_{\beta r, \alpha r, f} & 0
\end{array}\right] \\
& +\left[\begin{array}{cccc}
0 & 0 & 0 & 0 \\
0 & 0 & 0 & 0 \\
G_{\alpha r, \alpha s, T} & G_{\alpha r, \beta s, T} & 0 & G_{\alpha r, \beta r, T} \\
G_{\beta r, \alpha s, T} & G_{\beta r, \beta s, T} & G_{\beta T, \alpha r, T} & 0
\end{array}\right]
\end{aligned}
$$

$(L)$ 行列は対角線に関して対称であるが， $\alpha-\beta$ 両軸 間は非対称であり，LIM の構造的非対称性による䉓 気磁気的非刘称继を表しているのがわかる。

エネルギー保存則により推力は(51)式の上うに計算 される。

$$
F_{0}=\pi / \tau(\bar{i})^{\tau}(\bar{G})(\bar{i})
$$

(50)，(51)式は回転機のそれと全く同様の $4 \times 4$ の ステム・マトリックスを有しているので，回転機上同 手段で特性の解析が可能である。また，機械的出力方 程式を

$$
F_{m}=M \frac{d V_{r}}{d t}+B V_{r}+F_{l}
$$

ここで, $M$ は二次導体質量, $B$ は摩擦保数,

$F$ ，は目荷による逆制動力

とすると，(50)〜 (52)式加

$$
[\bar{X}(t)]=[\bar{A}(t)]\{\bar{X}(t)]+[\bar{B}(t)][\bar{u}(t)]
$$

の状態方程式が得られる。こてで，

$$
\begin{aligned}
& {[\bar{X}(t)]=\left[(\bar{i}), V_{r}\right]} \\
& {[\bar{u}(t)]=[(\bar{v}], 1)}
\end{aligned}
$$

\begin{tabular}{|c|c|}
\hline 一次铁心全長 (短二次) $(\mathrm{m})$ & 1.350 \\
\hline 一坎铁心蝠 (m) & 0.90 \\
\hline 毎政悔和のスロット数 $q$ & 3 \\
\hline 数 $p$ & 6 \\
\hline $1 コ イ$ ルたりの巻数 $N$ (turn) & 60 \\
\hline 1 相 1 極ちたりの巻数(画侧) $N p$ (turn) & 360 \\
\hline 分招洗係数 $K_{d I}$ & 0.960 \\
\hline 短领巻䋆数 $K_{p t}$ & 0.966 \\
\hline 巻線保数 $K_{\text {w } t}$ & 0.927 \\
\hline 極どッ千 & 0.225 \\
\hline 二次算体材望 & Al \\
\hline 二次涪体厚さ $(\mathrm{m})$ & 0.002 \\
\hline 二次䅺体長さ $(\mathrm{m})$ & 0.450 \\
\hline 二次等体䗎 (m) & 0.500 \\
\hline
\end{tabular}

$$
\begin{aligned}
& (\bar{A}(t))=\left[\begin{array}{cc}
-[\bar{L}]^{-1}\left([\bar{R})+\frac{\pi}{\tau}[\bar{G}]\right) & 0 \\
\frac{\pi}{\tau} \frac{[\bar{i}]^{T}[\bar{G}]}{M} & -\frac{B}{M}
\end{array}\right] \\
& {[\bar{B}(t)]=\left[\begin{array}{cc}
{[\bar{L}]^{-1}} & 0 \\
0 & -\frac{F_{l}}{M}
\end{array}\right]}
\end{aligned}
$$

である。

\section{4. 特性解析および寒測結果}

本文で提案した等価回路の有勃性を確加めるため に，表 2 のよう供試機について計算および実測を行 い，その結果を図5〜図8亿示す。

国 5 は定電王印加時の胃波数一推力特栍に 対して端 効果を無視した場合と考虑した場合の計算結果之実測 結果を比較したものである。図6は定電流印加時の図 5 と同様の計算結果および実測結果である。因 5, 図 6 加らかかるように，計算結果之実測結果がかなり一

表 2 供試機諸元

Table 2. The specification of the test machine.

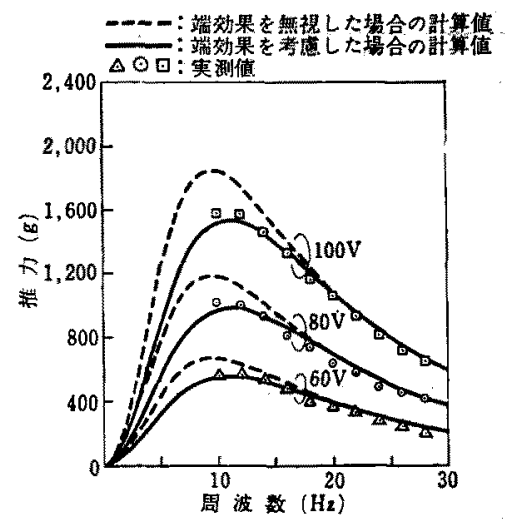

図 5 周波数一推力特性（定電圧甲加）

Fig. 5. Frequency-thrust characteristics (constant voltage excitation). 


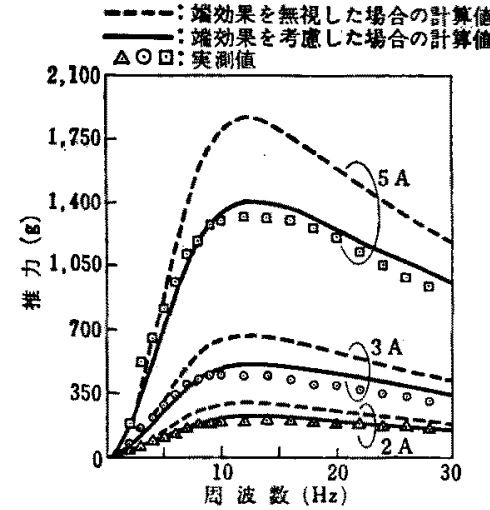

図 6 周波数一推力特性（定電流印加）

Fig. 6. Frequency-thrust characteristics (constant current excitation).

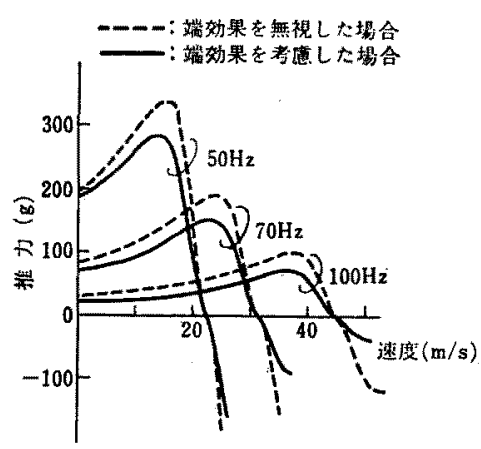

因 7 速度一推力特性（計算值）

Fig. 7. Speed-thrust characteristics (calculated value).

票していて，本等価回路は電王源駆動怙上び電流駆動 の両者供適用が可能であると考えられる。四 7 は定電 正印加時に周波数をパラメータとした走行速度一推力 の計算値である。図 8 は定電流印加時のすべり一推力 特性を示している。上記解析結果からみると，すべり の小さい頜域において端勃果の影響が大きく現われる か，端効果を考虑した計算結果は実剆值に加政り良く 一致していて，本等価回路の妥当性が立証できると思 われる。なお，因9にはステップ状の電圧を印加した 場合の過洨特性の解析例を示す。

\section{5. 位置決め制御への応用}

本章では前述の等価回路の応用例として LIM によ るサーボ制御を行い，以下に述べるうな制御方式お よび実験結果を示す。

(50)式のシステム方程式は図 4 の等価回路からもわ かるように時変非線形システムとなり，実際制御を行

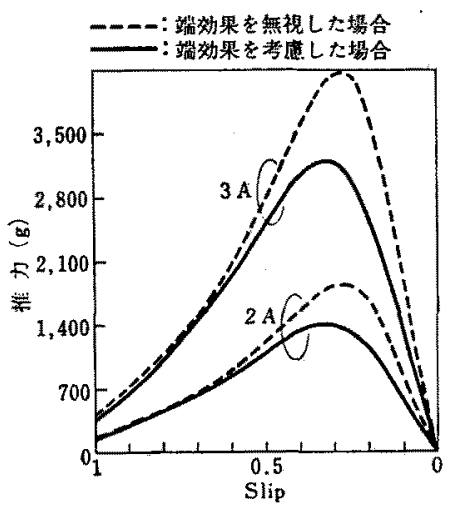

図 8 すべり一推力特性（計算值）

Fig. 8. Slip-thrust characteristics (calculated value).

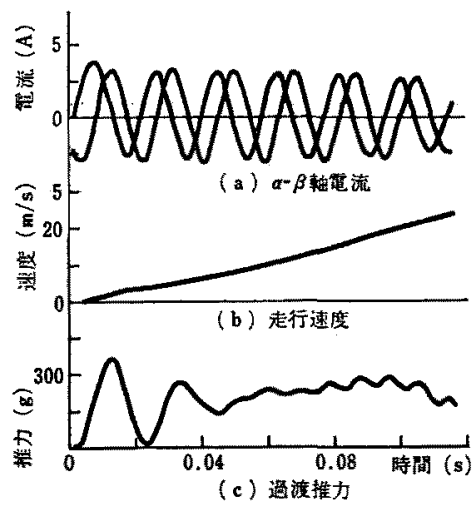

图 9 過渡状態解析例

Fig. 9. An analytical examples of transient state.

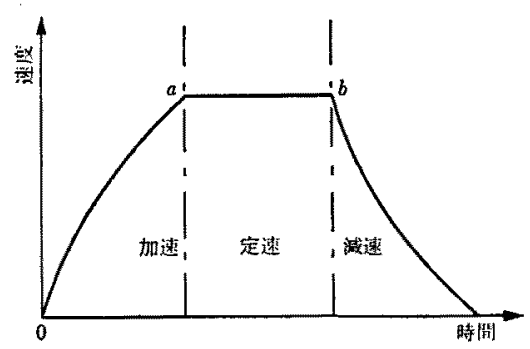

図 10 制御区間の分割

Fig. 10. The division of control section.

う場合リアルタイムでそれに関する最適入力解を求め るのは，現在の段階では不可能である。

そこで，図10のように原点から目標点までの間を 加速，定速，減速領域の三つの制御区間に分ける。加 速域では電源供給制御なし，定速域では情性走行，减 


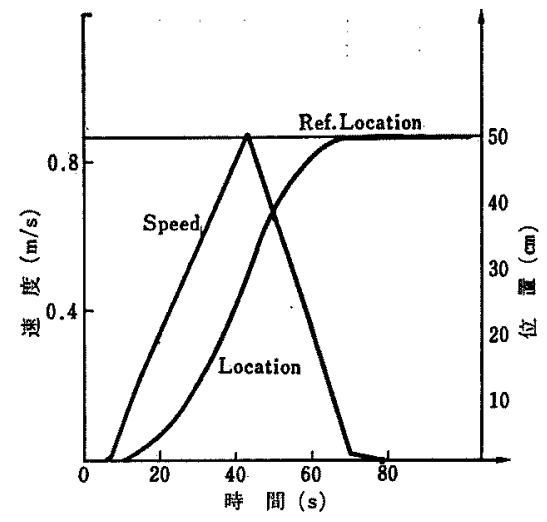

困 11 サーボ制御結果

Fig. 11. The result of servo control.

速域では逆制動力制御を行う。

いま, 減速域に入った時間 ( $b$ 点)を $t=0$ とおいて

$$
\begin{aligned}
& t=0: x=x_{0}, \frac{d x}{d t}=V_{0} \ldots \\
& t=T: x=x_{\mathrm{ref}}, \frac{d x}{d t}=0
\end{aligned}
$$

として

$$
X_{\mathrm{ref}}-X_{n} / V_{0}=M
$$

が成立する点を $b$ 点とする。また，ある時間において 必要となる推力を速度・位置データから計算する式を 次のように設定する。

$$
F(t)=M V_{n}^{2} /\left\{2\left(X_{n}-X_{\text {ref }}\right)\right\}
$$

(57)式加計算される推力を生ずるために必要な電 正ならびに周波数を得るために前述の等価回路を利用 する方式をとった。本等価回路加ら計算される入力量 は，その状態条件での端効果までも十分考虑された入 力量であり, 各ステップでの入力変数の操作において かなり向上された制御結果を得るととができる。今回 のサーボ制御では表 2 に示したように有効走行区間で ある一次鉄心長が短く，実制御区間が $50 \mathrm{~cm}$ 程度と なるため四 10 中定速部分を省略して制御を行い, 詥 差 $\pm 0.5 \mathrm{~mm}$ の十分满足できる結果が得られた。図 11 にその制御結果を示す。

\section{6. 結 䜽}

LIM の特性は電磁界の解析を行えばかなり良く把 㨋できるが，その解析法は制御システムに直接適用で きない。そとで, 場の解析より LIM 特有の端効果を 含んだ等価回路を導出し，それを制御システムに適用 する手法について検討した。

本文の成果として次のようなととが挙げられる。

（1）端効果の定性，定量的な考虑ができる。

（2）電圧，電流源駆動時の特性がとすに処理でき る。

（3）電王，電流瞬時変化住対する過渡時にす対忘 できる。

（4）端効果や時間的過渡状㦔にあ対応できる等価 回路であるが，等価回路定数計算はそれ称ど複 雑ではない。

（5）誘導機（回転形）のように $4 \times 4$ のシステム 行列であり，参考文献 ( 3 )のモデルと比へ, 計 算時間が大幅に削減できる。

（6）時間頜域で表されるので状態空間表現が可 能。

今後, 本等価回路の特長を生かし短二次 DLIM の 瞬時推力制御において，回転機の高性能制御法である 空げき磁束演算形べクトル制御，および瞬時磁束検出 法を併用する制御法に関する研究を行っていきたいと 思う。

終りに，本研究において有益な助言をいただいた本 学 石山助教授ならびに横井助手に感謝の意を表する。 (昭和 61 年 7 月 24 日受付)

$$
\text { 文献 }
$$

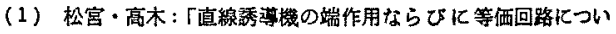

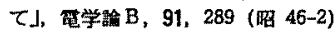

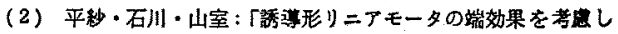
た等洒回路」，同上B，100，221 (燳 55-4)

(3) T. A. Lipo \& T. A. Nondahl: "Pole-by-pole d.q model of a Linear Induction Machine". IEEE Trans. Power Apparatus Syst., PAS-98, 629 (1979)

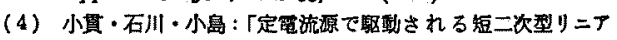

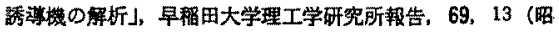
50) 